\title{
Adzuki beans (Vigna angularis) seed quality under several drying conditions
}

\author{
Qualidade de sementes de feijão adzuki (Vigna angularis) submetidas a diversas condições de secagem
}

\author{
Osvaldo RESENDE ${ }^{1 *}$, Dieimisson Paulo ALMEIDA², Lílian Moreira COSTA, \\ Udenys Cabral MENDES 3 , Juliana de Fátima SALES ${ }^{3}$
}

\begin{abstract}
This study analyzed the drying process and the seed quality of adzuki beans (Vigna angularis). Grains of adzuki beans, with moisture content of 1.14 (decimal dry basis) at harvest and dried until the moisture content of 0.11 (decimal dry basis.) were used. Drying was done in an experimental drier maintened at controlled temperatures of $30,40,50,60$, and $70{ }^{\circ} \mathrm{C}$ and relative humidity of 52.0, 28.0, 19.1, 13.1, and $6.8 \%$, respectively. Physiological and technological seed quality was evaluated using the germination test, Index of Germination Velocity (IGV), electrical conductivity, and water absorption, respectively. Under the conditions tested in the present study, it can be concluded that drying time for adzuki beans decreases with the higher air temperatures of 60 and $70{ }^{\circ} \mathrm{C}$, and it affected the physiological and technological seed quality. Thus, to avoid compromising adzuki seeds quality, it is recommended to promote its drying up to $50{ }^{\circ} \mathrm{C}$.
\end{abstract}

Keywords: physiological quality; drying conditions; technological quality; seed drying.

\section{Resumo}

Objetivou-se no presente trabalho analisar o processo de secagem do feijão adzuki (Vigna angularis), bem como avaliar a qualidade das sementes, submetidas à secagem em diversas condições de ar. Foram utilizados grãos de feijão adzuki (Vigna angularis), colhidos com teor de água de 1,14 (decimal base seca) e secos até o teor de 0,11 (decimal base seca). A secagem do feijão adzuki foi realizada em secador experimental mantido nas temperaturas controladas de $30,40,50,60$ e $70^{\circ} \mathrm{C}$ e umidades relativas de 52,0;28,0;19,1; 13,1 e 6,8\%, respectivamente. Para analisar a qualidade fisiológica e tecnológica das sementes realizou-se o teste de germinação, Índice de Velocidade de Germinação (IVG), condutividade elétrica e absorção de água, respectivamente. Nas condições em que foi desenvolvido o presente trabalho,conclui-se que o tempo de secagem do feijão adzuki diminui para as temperaturas mais elevadas do ar de 60 e $70{ }^{\circ} \mathrm{C}$ e afetam as qualidades fisiológica e tecnológica das sementes. Assim, para não haver comprometimento da qualidade das sementes do feijão adzuki recomenda-se promover a sua secagem até a temperatura máxima do ar de $50^{\circ} \mathrm{C}$.

Palavras-chave: qualidade fisiológica; condições de secagem; qualidade tecnológica; secagem de sementes.

\section{Introduction}

Edible beans are cultivated in almost all tropical and subtropical countries playing a key role in human nutrition, especially due to its low cost. It is a protein rich food, a popular food item grown throughout Brazil and preferred by people with diverse feeding habits and it is.

The genus Vigna has about 160 species, seven of which are cultivated. Among these, adzuki beans (Vigna angularis) are produced mostly in Asia (VIEIRA; VIEIRA; ANDRADE, 1992) and are consumed mainly in China, Japan, and Korea. Japan is the major producer and importer of adzuki beans, which occupies about 100 thousand hectares of planted area. There are no precise data about farmers, production, or planted area with this type of beans in Brazil, which is mostly used in Japanese colonies mainly as deserts and uncountable oriental delicacies (VIEIRA; VIEIRA; MOURA, 2000).

At the post-harvest stage, drying is the most widely used process to assure beans quality and stability taking into account that reducing the moisture content of the material reduces biological activity as well as chemical and physical changes that occur during storage (RESENDE et al., 2008a). However, drying at temperatures and air moisture that generate large rates of water removal can substantially affect seed quality (ALMEIDA et al., 2009).

Drying agricultural produce consists of the removal of high moisture content inside the grain by evaporation, generally caused by forced convection of heated air, thus allowing the maintenance of quality during storage for long periods (AFONSO JÚNIOR; CORRÊA, 1999).

The phenomenon of reducing the grain moisture content involves, simultaneously, the transfer of heat and mass, which can substantially change its quality, depending on the drying method and the conditions used (HALL, 1980).

Miranda et al. (1999) reported that soybean seed physiological quality was not affected after drying in a dryer

\footnotetext{
Received 24/8/2010

Accepted 28/8/2011 (005007)

${ }^{1}$ Instituto Federal Goiano - IF Goiano, Campus Rio Verde, CP 151, CEP 35701-970, Rio Verde, GO, Brasil, e-mail: osvresende@yahoo.com.br

2 Instituto Federal Goiano - IF Goiano, Campus Rio Verde, CP 66, CEP 75901-970, Rio Verde, GO, Brasil

3 Instituto Federal Goiano - IF Goiano, Rod. Sul Goiana, Km 01, Zona Rural, CEP 75901-970, Rio Verde, GO, Brasil

${ }^{*}$ Corresponding author
} 
with air flow of $28.4 \mathrm{~m}^{3} / \mathrm{min} / \mathrm{t}$, and $50{ }^{\circ} \mathrm{C}$. The temperature of the mass did not exceed $47.8^{\circ} \mathrm{C}$. However, Ahrens and Lollato (1997) working with the same type of silo dryer, found no satisfactory results after dry bean seeds inflated with air to $35^{\circ} \mathrm{C}$ due to reduction in physiological seed quality caused probably by high airflow and the delay in drying due to the high initial moisture content. In general, according to Ahrens, Villela and Doni-Filho et al. (2000), the Poaceae seeds are less sensitive to thermal damage during the drying process than the Fabaceae seeds due to the fact that the latter have more exposed embryos than the former. Seed germination is an organized consequence of metabolic activities divided into phases resulting in the formation of a seedling. This is a critical step of the vegetable biocycle since it is associated with several extrinsic (physical environment) and intrinsic factors, i.e., physio-metabolic processes (POPINIGIS, 1985). This event can be affected by the drying process, which can cause physiological and mechanical damage in the seed.

The germination process starts with water soaking by the seed tissues followed by the return of metabolic activities, especially by the synthesis of new enzymes and increased activity of pre-existing hydrolases and the reserve composts mobilization for growth of the embryo axis (SALES, 2002).

Electrical conductivity test is used in the evaluation of seed vigor (VIEIRA; KRYZANOWSKI, 1999). This test determines the amount of electrolytes leached from a seed soaking solution, and it is a good indicator of mechanical damage in the seeds. This test has presented good performance in studies evaluating mechanical damage in bean seeds, such as those reported for cultivar IAPAR 44 (SANTOS et al., 2003), Carioca cultivar (ARAGÃO et al., 2002), and variety Ouro Negro 1992 (ANDRADE et al., 1999).

Considering the importance of drying tropical agricultural produce and the range of bean species, this study analyzed adzuki beans (Vigna angularis) drying process and evaluated seed quality, subjected to drying under several air conditions, through the analyses of germination percentage, Index of Germination Velocity (IGV), electrical conductivity, and water soaking.

\section{Materials and methods}

This study was carried out in the Post-harvest Plant Products Laboratory of the Instituto Federal de Educação, Ciência e Tecnologia Goiano - Campus Rio Verde (IF Goiano - Campus Rio Verde), located in the city of Rio Verde, GO.

Adzuki beans (Vigna angularis) grains were cultivated in the summer cropping season of 2007/2008 at the experimental area of IF Goiano - Campus Rio Verde, manually harvested, with moisture content of approximately 1.14 (decimal dry basis).

The moisture content of the product was determined gravimetrically using an oven at $105 \pm 1{ }^{\circ} \mathrm{C}$, for 24 hours in three replicates (BRASIL, 2009).

Drying of adzuki beans was done in an experimental drier maintained at controlled temperatures of 30,40, 50, 60, and $70{ }^{\circ} \mathrm{C}$ and relative humidity of $52.0,28.0,19.1,13.1$, and $6.8 \%$, respectively. Removable aluminum trays were placed inside the drier containing $0.3 \mathrm{~kg}$ beans, each in four repetitions. The samples were periodically weighed during the drying process until the end point of drying, approximately 0.11 (decimal d.b.), defined as the recommended moisture content for safely storing the product. The reduction in moisture content during the drying process was followed by gravimetric determination of weight loss (gravimetric method) using an analytical balance with readability as low as $0.01 \mathrm{~g}$, knowing the initial moisture content of the product, to reach the final moisture content.

Temperature and relative humidity inside the experimental drier were monitored usinga a psychrometer.

The germination test was performed with 4 sub-samples of 30 seeds each in rolls with germitest paper in a "Mangesdorf" germinator adjusted to $25 \pm 2{ }^{\circ} \mathrm{C}$. The amount of water added was equivalent to 2.5 times the mass of the dry substrate to adequately moisten the seeds and, consequently, to standardize the test. The readings were done from the $2^{\text {nd }}$ day to the $39^{\text {th }}$ day of sowing, according to the criteria established by the Rules for Seed Analysis with adaptation (BRASIL, 2009). In this evaluation, the average percent germination and the index of germination velocity (IGV) were determined.

For the determination of water absorption after drying, the methodology described by Resende et al. (2008b) was used.

The samples were subjected to soaking in distilled water for a period of 12 hours. Product soaking was done in the laboratory environment, at $25 \pm 2{ }^{\circ} \mathrm{C}$. Beakers ( $100 \mathrm{~mL}$ capacity) containing $80 \mathrm{~mL}$ distilled water with $20 \mathrm{~g}$ beans were used, mass ratio 4:1. After the maceration period, the samples were removed from the beakers and placed over paper towels to blot the surface water for 2 minutes. The moisture content after soaking was obtained by the Equation 1.

$U^{*}=\frac{\mathrm{M}_{\mathrm{e}}-\mathrm{M}_{\mathrm{S}}}{\mathrm{M}_{\mathrm{S}}}$

where: $U^{*}$ : Moisture content of the product, (decimal dry basis); $\mathrm{M}_{\mathrm{e}}$ : Mass after soaking, $\mathrm{kg} ; \mathrm{M}_{\mathrm{s}}$ : Dry mass of the product, $\mathrm{kg}$.

The test of electric conductivity was performed in the bean grains, according to the methodology described by Vieira and Krzyzanowski (1999). Four sub-samples of 50 grains were weighed for each treatment. The samples were placed in plastic cups contained $75 \mathrm{~mL}$ deionized water and maintained in controlled temperature chamber at $25^{\circ} \mathrm{C}$ for 24 hours. Subsequently, electric conductivity was measured with a conductivimeter.

The experimental design was completely randomized with 5 treatments (drying temperatures at $30,40,50,60$, and $70{ }^{\circ} \mathrm{C}$ ), with four replications. The data were analyzed using Analysis of variation and regression. The models were selected based on the significance of the equation ( $F$ test at $5 \%$ probability), the coefficient of determination $\left(\mathrm{R}^{2}\right)$, and the knowledge of the development of the biological phenomenon.

\section{Results and discussion}

Figure 1 presents the average values of moisture content of adzuki beans grains during drying at several temperature and relative humidity. 
The time required for adzuki beans to reach the moisture content of 0.11 (decimal d.b.) was 49.0, 23.0, 16.5, 10.0, and 7.0 hours, for the temperatures of $30,40,50,60$, and $70^{\circ} \mathrm{C}$, respectively (Figure 1 ). Therefore, the time required for drying was smaller at $70^{\circ} \mathrm{C}$, in relation to the other treatments analyzed $\left(30,40,50\right.$, and $\left.60^{\circ} \mathrm{C}\right)$ indicating the greater speed of water removal under this condition. As expected, time was affected by drying temperature, with the greatest difference between the drying temperatures of 70 and $30^{\circ} \mathrm{C}$. Similar results were observed by Corrêa et al. (2007) during drying of red beans (Phaseolus vulgaris L.), with time required for the beans to reach the moisture content of $12 \%$ (wet basis) of 20.0, 8,0, and 5.3 hours, for the temperatures of $35 ; 45$, and $55^{\circ} \mathrm{C}$, respectively.

It can also be seen in Figure 1 that as air temperature increased, there was greater water removal rate. This behavior was also observed for several agricultural products: hazelnuts (OZDEMIR; DERVES, 1999); rough rice (BASUNIA; ABE, 2001); sultana grapes (YALDIZ; ERTEKIN; UZUN, 2001); grapes (AZZOUZ et al., 2002); green and red peppers (KAYMAK-ERTEKIN, 2002); red pepper (AKPINAR; BICER; YILDIZ, 2003); prickly pear (LAHSASNI et al., 2004); eggplant (ERTEKIN; YALDIZ, 2004); parboiled wheat (MOHAPATRA; RAO, 2005); adzuki beans (ALMEIDA et al., 2009); and jatropha (ULLMANN et al., 2010).

Figures 2 and 3 present, respectively, the germination percentage and the Index of Germination Velocity (IGV) of adzuki beans evaluated immediately after drying under several conditions of temperature and relative humidity.

The average percentage germination was $95,96,94,71$, and $20 \%$ for the drying temperatures of $30,40,50,60$, and $70{ }^{\circ} \mathrm{C}$, and relative humidity of $52.0,28.0,19.1,13.1$, and $6.8 \%$, respectively (Figure 2).

The average IGV values were 9.1, 11.0, 10.8, 6.8, and 2.0 for the drying temperatures of $30,40,50,60$, and $70^{\circ} \mathrm{C}$, respectively (Figure 3). Therefore, germination percentages and IGV were smaller for seeds dried at 60 and $70{ }^{\circ} \mathrm{C}$ in comparison with all other treatments analyzed $\left(30,40\right.$, and $\left.50{ }^{\circ} \mathrm{C}\right)$ indicating the greater damage caused in the seed cell membranes under these conditions. The physiological seed quality measured by the germination and IGV tests were greatly affected at the drying temperatures of 60 and $70{ }^{\circ} \mathrm{C}$, and the germination values were below the minimum established for beans market in Brazil is $80 \%$ (BRASIL, 2005). The high initial moisture content of seeds, $53 \%$ (wet basis), reduced during drying to $10.5 \%$ (wet basis), which could have affected the germination and IGV results for the beans subjected to the treatments at 60 and $70^{\circ} \mathrm{C}$. According to Afonso Júnior and Corrêa (1999), seed harvested at higher moisture content are more sensitive to quality loss during drying, especially at elevated temperatures due to the increased rate of removal of water from them. Drying bean seeds at $35{ }^{\circ} \mathrm{C}$ with an initial moisture content of $33.4 \%$ (wet basis) until the final moisture content of $11.0 \%$ (wet basis), Andrade et al. (2006) found lower germination and vigor values compared to those of bean seeds subjected to the same drying conditions but with initial moisture contents of 25.1 and $29.4 \%$ (wet basis). In addition, the variation in germination and IGV for drying adzuki beans, in the range of 30 to $70{ }^{\circ} \mathrm{C}$, can be

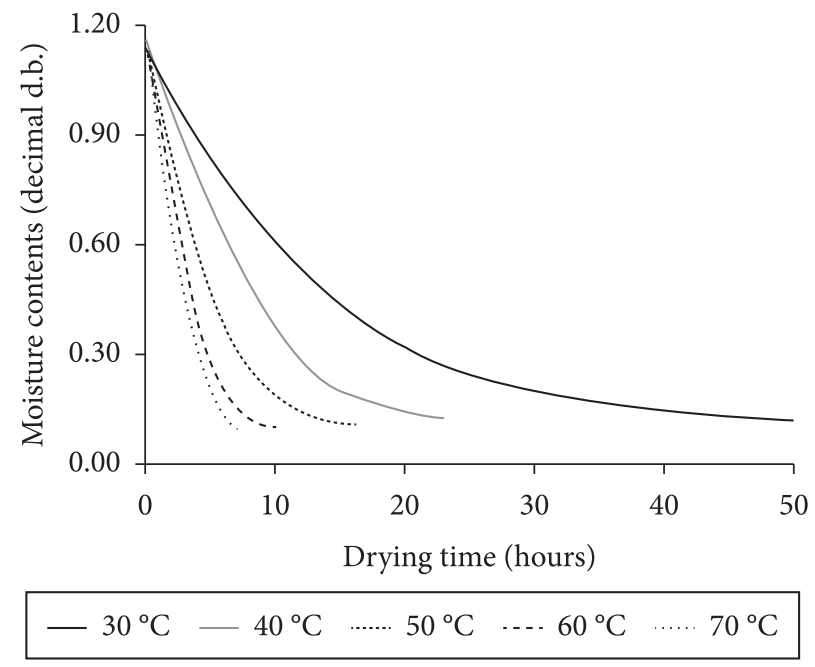

Figure 1. Average values of moisture contents of adzuki beans grains (decimal d.b.) as a function of drying time (hours) for the temperatures of $30,40,50,60$, and $70^{\circ} \mathrm{C}$.

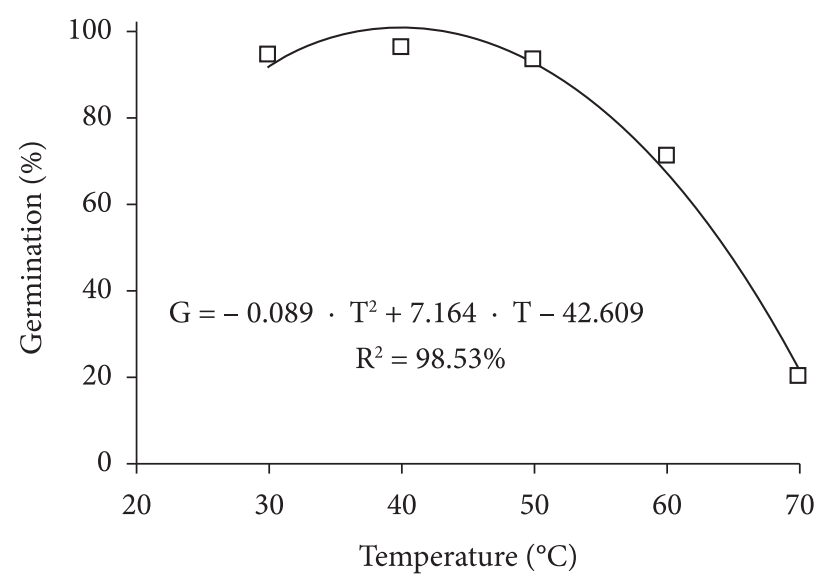

Figure 2. Average percentage of germinated seeds $(\mathrm{G})$ of adzuki beans as a function of drying temperature $(\mathrm{T})$ of $30,40,50,60$, and $70{ }^{\circ} \mathrm{C}$.

adequately described by a quadratic equation, as observed by the determination coefficients values above 98.5\% (Figures 2 and 3 ).

Figure 4 presents the results of electrical conductivity of adzuki beans subjected to drying under several conditions of temperature and relative humidity.

The average values of the test of electric conductivity increased quadratically with increasing drying temperatures presenting magnitudes of 55.7, 72.4, 90.8, 189.6, and $286.9 \mu \mathrm{S} . \mathrm{cm}^{-1} \cdot \mathrm{g}^{-1}$, respectively, for the temperatures values of 30 , $40,50,60$, and $70^{\circ} \mathrm{C}$ (Figure 4). Therefore, the highest average electric conductivity value was found at $70{ }^{\circ} \mathrm{C}$ in comparison to the other treatments analyzed $\left(30,40,50\right.$, and $\left.60^{\circ} \mathrm{C}\right)$ indicating greater damage in the seeds under this condition since an increase in the drying temperature, increases the rate of water removal from the seed causing micro fissures at the cell level. The average electrical conductivity values were affected by the drying temperature, with the greatest difference found between the treatments 30 and $70^{\circ} \mathrm{C}$. 


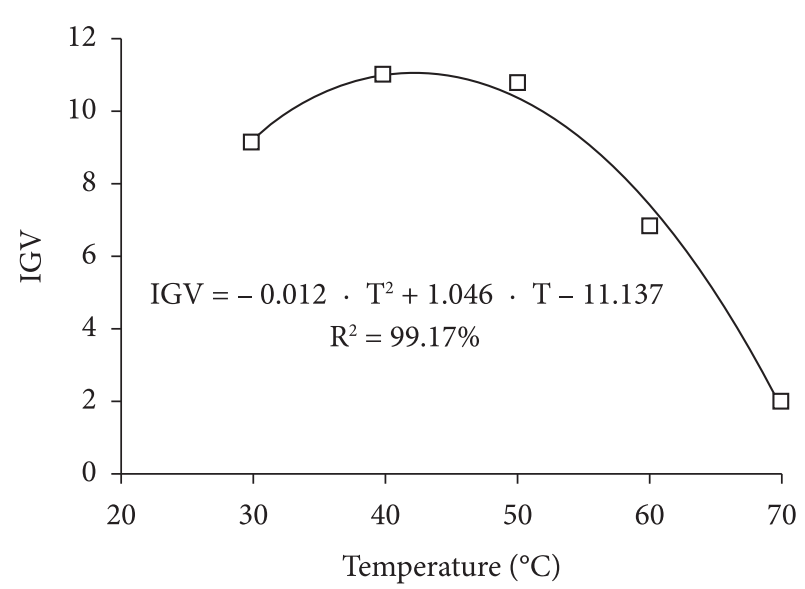

Figure 3. Average Index of Germination Velocity (IGV) of adzuki beans seeds as a function of drying temperatures of $30,40,50,60$, and $70^{\circ} \mathrm{C}$.

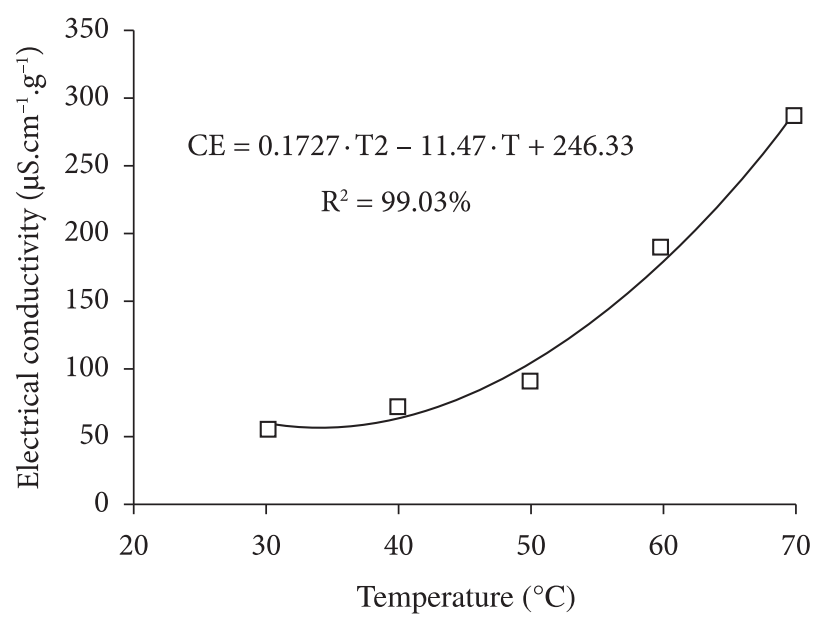

Figure 4. Average values of electrical conductivity (CE) in the soaking solution of adzuki beans as a function of drying temperatures $(\mathrm{T})$ of $30,40,50,60$, and $70{ }^{\circ} \mathrm{C}$.

As expected, the seeds initial moisture content (53\%, wet basis) affected more the treatments with greater temperatures $\left(50,60\right.$, and $\left.70{ }^{\circ} \mathrm{C}\right)$, expressed by the greater conductivities. Similar results were found by Andrade et al. (1999) investigating the drying process of bean seeds (Phaseolus vulgaris $\mathrm{L}$.) variety "Ouro Negro 1992" with initial moisture content of 33.4\% (wet basis) and final moisture content of $11.0 \%$ (wet basis). Furthermore, a quadratic equation adequately described the evolution of electric conductivity of adzuki beans in relation to the drying temperatures (Figure 4).

Figure 5 presents the average values of water absorption by adzuki beans evaluated immediately after drying under several temperatures.

The average values of water absorption increased linearly according to the different drying air conditions presenting values of $0.75,0.89,0.90,1.07$, and 1.20 (decimal dry basis) for the drying temperatures of $30,40,50,60$, and $70^{\circ} \mathrm{C}$, respectively (Figure 5). The drying temperature of $70^{\circ} \mathrm{C}$ presented the greatest water absorption indicating greater mechanical damage

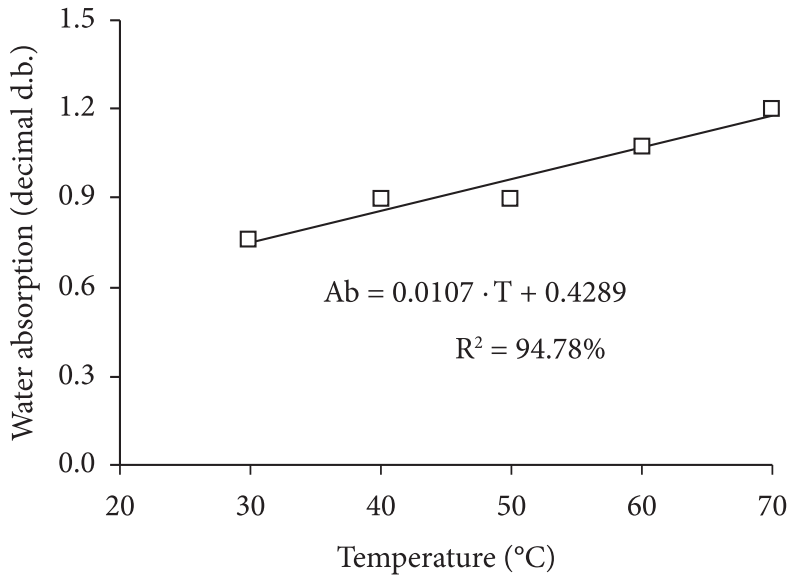

Figure 5. Average values of water absorption $(\mathrm{Ab})$ by adzuki beans as a function of drying temperatures (T) of $30,40,50,60$, and $70^{\circ} \mathrm{C}$.

due to the high drying temperature than that of the other temperatures $\left(30,40,50\right.$, and $\left.60^{\circ} \mathrm{C}\right)$. According to Resende et al. (2008b), in a study on different soaking temperatures of common beans as a function of storage time, greater water absorption was found for the periods that presented high pest infestation (Acanthochelides obtectus) due to greater mechanical damage in bean seeds. Investigating the drying of bean seeds with initial moisture content of $25 \%$ (wet basis) to final moisture content of 13\% (wet basis) in the sun and intermittent dryer, Ahrens and Lollato (1997) found that the rate of cracked seeds increased during intermittent drying in the dryer at $60^{\circ} \mathrm{C}$.

It is also observed in Figure 5 that the simple linear model represents well the variation in water absorption as a function of drying temperature, represented by the high determination coefficient $\left(\mathrm{R}^{2}\right)$.

\section{Conclusions}

Under the conditions of this study, it can be concluded that increasing the drying air temperature reduces the drying time. Air temperatures of 60 and $70{ }^{\circ} \mathrm{C}$ negatively affected the physiological and technological seed quality. Therefore, in order to avoid damages to adzuki beans quality, it is recommended that the drying temperature should not exceed $50^{\circ} \mathrm{C}$.

\section{Acknowledgements}

The authos acknowledge the Conselho Nacional de Desenvolvimento Científico e Tecnológico $(\mathrm{CNPq})$ and the Instituto Federal Goiano - Campus Rio Verde (IF Goiano Campus Rio Verde) for the financial support.

\section{References}

AFONSO JÚNIOR, P. C.; CORRÊA, P. C. Comparação de modelos matemáticos para descrição da cinética de secagem em camada fina de sementes de feijão. Revista Brasileira de Engenharia Agrícola e Ambiental, v. 3, n. 3, p. 349-353, 1999.

AHRENS, D. C.; LOLLATO, M. A. Eficiência de secadores estacionário de fluxo radial e intermitente rápido: efeitos sobre a qualidade de 
sementes de feijão. Revista Brasileira de Sementes, v. 19, n. 1, p. 28-33, 1997.

AHRENS, D. C.; VILlELA A. F.; DONI-FILHO, L. Secagem estacionária de sementes de aveia-branca (avena sativa L.) empregando diferentes temperaturas do ar. Revista Brasileira de Sementes, v. 22, n. 2, p. 6-11, 2000.

AKPINAR, E. K.; BICER, Y.; YILDIZ, C. Thin layer drying of red pepper. Journal of Food Engineering, v. 59, n. 1, p. 99-104, 2003. http://dx.doi.org/10.1016/S0260-8774(02)00425-9

ALMEIDA, D. P. et al. Cinética de secagem do feijão adzuki (Vigna angularis). Global Science and Technology, v. 2, n. 1, p. 72-83, 2009.

ANDRADE, E.T. et al. Avaliação de dano mecânico em sementes de feijão por meio de condutividade elétrica. Revista Brasileira de Engenharia Agrícola e Ambiental, v. 3, n.1, p. 54-60, 1999.

ANDRADE, E. T. et al. Cinética de secagem e qualidade de sementes de feijão. Engevista, v. 8, n. 2, p. 83-95, 2006.

ARAGÃO, C. A. et al. Sementes de feijão submetidas a ciclos e períodos de hidratação-secagem. Scientia Agricola, v. 59, n. 1, p. 87-92, 2002.

AZZOUZ, S. et al. Moisture diffusivity and drying kinetic equation of convective drying of grapes. Journal of Food Engineering, v. 55, n .4, p. 323-330, 2002.

BASUNIA, M. A.; ABE, T. Moisture desorption isotherms of mediumgrain rough rice. Journal of Stored Products Research, v. 37, n. 3, p. 205-219, 2001. http://dx.doi.org/10.1016/S0022-474X(00)00022-9

BRASIL. Ministério da Agricultura, Pecuária e do Abastecimento. Instrução Normativa n. 25 de 16 de dezembro de 2005. Estabelece normas específicas e os padrões de identidade e qualidade para produção e comercialização de sementes de algodão, arroz, aveia, azevém, feijão, girassol, mamona, milho, soja, sorgo, trevo vermelho, trigo, trigo duro, triticale e feijão caupi. Seção 1, Diário Oficial da República Federativa do Brasil. Brasília, DF, 20 dez. 2005, Seção 1, p. 18.

BRASIL. Ministério da Agricultura e Reforma Agrária. Secretaria Nacional de Defesa Agropecuária. Regras para análise de sementes, 2009. 399 p.

CORRÊA, P. C. et al. Modelagem matemática para a descrição do processo de secagem do feijão (Phaseolus vulgaris L.) em camadas delgadas. Engenharia Agrícola, v. 27, n. 2, p. 501-510, 2007.

ERTEKIN, C.; YALDIZ, O. Drying of eggplant and selection of a suitable thin layer drying model. Journal of Food Engineering, v. 63, n. 3, p. 349-59, 2004. http://dx.doi.org/10.1016/j.jfoodeng.2003.08.007

HALL, C.W. Drying and storage of agricultural crops. 6. ed. Westport, 1980.381 p.

KAYMAK-ERTEKIN, F. Drying and rehydrating kinetics of green and red peppers. Journal of Food Science, v. 67, n.1, p.168-175, 2002. http://dx.doi.org/10.1111/j.1365-2621.2002.tb11378.x
LAHSASNI, S. et al. Drying kinetics of prickly pear fruit (Opuntia ficus indica). Journal of Food Engineering, v. 61, n. 2, p.173-179, 2004. http://dx.doi.org/10.1016/S0260-8774(03)00084-0

MIRANDA, L. C.; SILVA, W. R.; CAVARIANI, C. Secagem de sementes de soja em silo com distribuição radial do fluxo de ar: efeitos sobre a qualidade das sementes. Pesquisa Agropecuária Brasileira, v. 34, n.11, p. 2109-2121, 1999. http://dx.doi.org/10.1590/S0100204X1999001100018

MOHAPATRA, D.; RAO, P. S. A thin layer drying model of parboiled wheat. Journal of Food Engineering, v. 66, n. 4, p. 513-518, 2005. http://dx.doi.org/10.1016/j.jfoodeng.2004.04.023

OZDEMIR, M.; DEVRES, Y. O. The thin layer drying characteristics of hazelnuts during roasting. Journal of Food Engineering, v. 42, n. 4, p. 225-233, 1999. http://dx.doi.org/10.1016/S0260-8774(99)00126-0

POPINIGIS, F. Fisiologia da semente (Seed physiology). 2. ed. Brasília: Agiplan, 1985. 289 p.

RESENDE, O. et al. Propriedades físicas do feijão durante a secagem: Determinação e Modelagem. Ciência e Agrotecnologia, v. 32, n. 1, p. 225-230, 2008a. http://dx.doi.org/10.1590/S141370542008000100033

RESENDE, O. et al. Avaliação da qualidade tecnológica do feijão durante o armazenamento. Ciência e Agrotecnologia, v. 32, n. 2, p. 517 524, 2008b. http://dx.doi.org/10.1590/S1413-70542008000200027

SALES, J. F. Atividade da celulase sobre o processo germinativo de sementes de cafeeiro (Coffea arabica L.). 2002. 38 f. Dissertação (Mestrado em Agronomia)- Universidade Federal de Lavras, Lavras, 2002.

SANTOS, C. M. R.; MENEZES, N. L.; VILLELA, F. A. Teste de deterioração controlada para avaliação do vigor de sementes de feijão. Revista Brasileira de Sementes, v. 5, n. 2, p. 28-35, 2003. http://dx.doi.org/10.1590/S0101-31222003000400005

ULLMANN, R. et al. Qualidade das sementes de pinhão manso submetidas à secagem artificial. Revista Ciência Agronômica, v. 41, n. 3, p. 442-447, 2010.

VIEIRA, R. F.; VIEIRA, C.; ANDRADE, G. A. Comparações agronômicas de feijões dos gêneros Vigna e Phaseolus com o feijãocomum (Phaseolus vulgaris L.). Pesquisa Agropecuária Brasileira, v. 27, n. 6, p. 841-850, 1992.

VIEIRA, R. F.; VIEIRA, C.; MOURA, W. M. Comportamento do feijão Azuki em diferentes épocas de plantio em Coimbra e Viçosa. Revista Ceres, v. 47, p. 411-420, 2000.

VIEIRA, R. D.; KRZYZANOWSKI, F. C. Teste de condutividade elétrica. In: KRZYZANOWSKI, F. C.; VIEIRA, R. D.; FRANÇA NETO, J. B. (Eds.). Vigor de sementes: conceitos e testes. Londrina: ABRATES, 1999. cap. 4, p.1-26.

YALDIZ, O; ERTEKIN, C.; UZUN, H. I. Mathematical modeling of thin layer solar drying of sultana grapes. Energy, v. 26, n. 5, p. 457-465, 2001. http://dx.doi.org/10.1016/S0360-5442(01)00018-4 